\title{
ADAT "ANGKAN-ANGKANAN" SUKU KOMERING SEBAGAI PINTU MASUK HAMBA LINTAS BUDAYA
}

Oleh: Darmanto ${ }^{1}$

\begin{abstract}
The world of ministry in Indonesia is very diverse with many of tribes, cultures and languages

- Often minstersare faced with many obstacles, one being cultural barriers or customs that often clash with the demands of the Gospel. There are three principles in addressing the culture or customs that we should remember, namely: there are culture values and customs that can be retained, there are culture values and customs that need to be modified and aligned with biblical teaching, but there is also a cultural values and customs that must be rejected as contrary to the truth of the gospel. Among the Komering people group, for example, there is an existing tribal custom called "Angkan - angkanan" that welcomes outsider into the community as if they are family; and this is an effective way for crosscultural servant to enter and gain the audience of the tribe.
\end{abstract}

Key words : gospel, culture, komering, angkan-angkanan

\section{Pendahuluan}

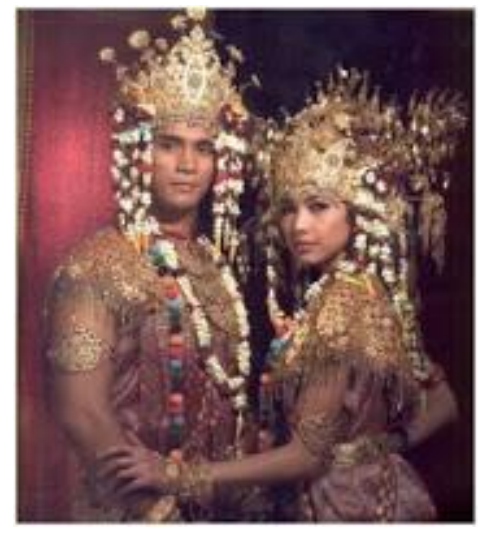

Suku Komering ${ }^{2}$, adalah salah satu suku yang bermukim dan tersebar di pesisir danau Ranau dan sungai Komering di wilayah kabupaten Ogan Komering provinsi Sumatra Selatan. Populasi mereka saat ini adalah yang terbesar dari sensus terakhir sebesar 270.000 orang.

Suku Komering termasuk salah satu suku tertua yang ada di Sumatra(Proto Malayan), seperti Mentawai, Enggano, Nias, Batak, Kubu dan Orang Laut. Kata komering, diperkirakan berasal dari istilah bahasa Hindu purba yang diberikan oleh pedagang-pedagang India, yang berarti "pinang". Sekitar abad ke 19 daerah tersebut sering dikunjungi oleh pedagang-pedagang dari India

Suku Komering di wilayah Kabupaten Ogan Komering hidup berdampingan dengan suku Ogan, suku Daya, suku Ranau, suku Semendo dan suku Kisam.Dalam struktur

1 Darmanto adalah Dosen STT Nazarene dan saat ini sebagai Ketua Program Studi Teologi; menyelesaikan program S1 dan S2 Teologi Kependetaan di STT Nazarene dan saat juga aktif dalam Pelayanan Pengembangan Anak dan Pelayanan Lintas Budaya.

2 Nama Komering berasal dari nama Sungai Komering, yang menjadi sumber kehidupan mereka. ada dua kelompok orang Komering yaitu Komering Ilir dan Komering Ulu; Komering Ilir tinggal di Kecamatan Tanjung Lubuk disekitar kota Kayu Agung, Kabupaten Ogan Komering Ilir. Sedangkan Komering Ulu tinggal di Kabupaten Ogan Komering Ulu di Kecamatan Cempaka, Buay Madang, Belitang, Simpang, Martapura dan Kotamadya Baturaja. 
kemasyarakatan suku Komering, berdasarkan bahasa dan budaya, dibagi menjadi 2 kelompok, yaitu:

- Pendukung budaya dan bahasa Seminung, terdiri dari suku-suku Komering, Ranau dan Daya.

- Pendukung budaya Dempo,, yaitu suku-suku Ogan, Semendo dan Kisam.

Suku Komering sangat teguh mempertahankan budaya dan adat-istiadatnya, walaupun berada diantara budaya Melayu yang terus berkembang, terutama bahasa Komering yang sampai saat ini masih terpelihara dengan baik. Suku Komering adalah bangsa yang sangat ramah dan sangat menunjukkan sikap kekeluargaan terhadap siapapun, tradisi suka menolong tertanam dalam kehidupan sehari-hari mereka. Suku Komering saat ini mayoritas adalah pemeluk agama Islam.

Suku Komering, kalau dilihat dari segi fisik, menunjukkan kalau mereka adalah termasuk dari ras mongoloid, yang termasuk bangsa Proto-Malayan. Diperkirakan berasal dari daratan tinggi Yunnan di China Selatan, atau juga bisa berasal dari daratan Indochina sekitar Burma dan Kamboja, yang memasuki wilayah Sumatra ini sejak ribuan tahun sebelum Masehi, bersama kelompok proto-malayan lain yang bermigrasi memasuki wilayah pulau Sumatra. Hidup tersebar mereka di wilayah Sumatra bagian Selatan. Suku-suku bangsa Proto Melayu ini membawa budaya asal mereka, dan hidup selama ribuan tahun. Pada sekitar abad 2 Masehi, suku bangsa Melayu masuk secara besar-besaran membawa budaya Melayu, dan banyak terjadi perkawinan campur antara suku Komering dengan sukusuku Melayu. Sehingga bangsa Komering yang populasinya sedikit, terdesak dan lambat-laun terserap ke dalam tradisi Melayu. Saat ini beberapa penulis mengelompokkan suku Komering ke dalam kelompok Melayu.

Ada satu versi yang dikumpulkan dari beberapa cerita yang dihubung-hubungkan dari beberapa budaya yang didapat di wilayah Sumatra Selatan dan Lampung. Menurut masyarakat Lampung di daerah Lampung bahwa suku Komering termasuk bagian dari suku Lampung yang sama-sama berasal dari Kepaksian Sekala Brak. Sekala Brak diperkirakan berada di Gunung Pesagi, yang kemungkinan adalah sebuah kerajaan yang berdiri pada masa Hindu Budha pada abad ke 3 Masehi. Kerajaan Paksi Sekala Brak diperkirakan mengalami dua era yaitu era Keratuan Hindu Budha dan era Kesultanan Islam. Dari Sekala Brak ini lah yang disebutkan sebagai tempat asal suku Lampung dan juga diperkirakan suku Komering berasal.

Versi lain mengatakan bahwa suku Komering berasal dari Pagaruyung. Dimana Pagaruyung adalah bangsa Minangkabau yang deutro-malayan. Sedangkan keberadaan suku Komering sebenarnya jauh lebih tua dari suku bangsa Minangkabau. Di riwayatkan pendiri Sekala Brak berasal dari Pagaruyung? Terjadi keanehan di sini. Kerajaan Sekala Brak yang telah ada sejak abad ke 3, sedangkan Kerajaan Pagaruyung abad-15, atau menurut catatan sejarah Pagaruyung berdiri pada abad 13. Mungkinkah Kerajaan Sekala Brak yang jauh lebih tua pada abad ke 3, didirikan oleh orang dari Kerajaan Pagaruyung yang berdiri pada abad 13.

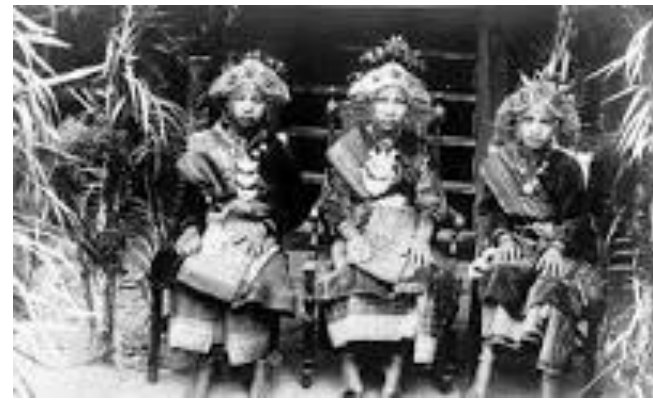

Sedangkan menurut cerita turun-temurun yang tersimpan dalam masyarakat suku Komering, bahwa pada sebuah ceritera rakyat yang mengatakan bahwa nenek moyang Komering dan nenek moyang orang Batak, dahulunya adalah hidup dan berasal dari suatu tempat yang sama. Dikatakan nenek moyang kedua suku ini adalah dari 2 orang yang bersaudara, dan sering terjadi "senda gurau" untuk menyatakan 
masing-masing nenek moyang merekalah yang tertua. Cerita ini walau hanya sebuah cerita rakyat, tetapi cukup diyakini oleh sebagian masyarakat suku Komering.

Walaupun banyak versi dan klaim tentang asal usul suku Komering, yang mana menurut orang Lampung, suku Komering adalah bagian dari suku Lampung. Sedangkan menurut orang Melayu, bahwa suku Komering adalah Melayu juga. Tetapi bagi suku Komering, mereka adalah mereka, Komering adalah Komering, bukan Melayu. Sedangkan dengan suku Lampung, mereka mengakui bahwa dengan suku Lampung mereka memang satu rumpun dan berasal dari suatu tempat yang sama.

\section{Nilai-nilai Kehidupan Suku Komering}

Penulis lahir dan dibesarkan ditengah-tengah Suku Komering, di daerah Buay madang Kabupaten Ogan Komering Ulu, Sumatera Selatan. Walaupun penulis bukan asli orang Komering, tetapi karena hidup keseharian bersama mereka, bersekolah dari Sekolah Dasar sampai Sekolah Pendidikan Guru, bekerja mengajar, berteman dan bersahabat dengan temanteman dari suku ini; juga aktifitas sosial masyarakat baik hubungan pekerjaan, jual beli di pasar juga acara-acara adat suku ini yang penulis ikuti, sehingga penulis sangat memahami budaya bahkan penulis bisa bertutur dalam bahasa suku ini. Suku Komering terkenal dengan sifat yang temperamental atau mudah marah, mudah tersinggung dan cenderung mudah berkelahi sampai penumpahan darah; bahkan memiliki dan memelihara dendam pribadi sebagai dendam keluarga bahkan dendam marga/suku. Orang pendatang terutama suku Jawa dan Bali di daerah ini kurang senang bergaul dengan mereka dengan alasan untuk keamanan pribadi atau agar tidak berkonflik dengan mereka.

Namun dibalik itu semua sesungguhnya bila kita bisa menyelami pola hidup dan budaya mereka tentu kita akan memiliki penilaian yang jauh berbeda dengan anggapananggapan umum yang telah beredar menjadi cap bagi suku ini; karena biasanya yang terjadi adalah ketidak pahaman atau kurangnya memahami adat istiadat menjadikan kesalahpahaman dan konflik terjadi. Praduga penulis sementara adalah kemungkinan ini yang menjadikan kurangnya Hamba Tuhan Lintas Budaya yang masuk ke daerah ini karena alasan-alasan di atas yang merupakan stigma dan kabar burung yang maksudnya adalah sebenarnya orang belum pernah datang dan mengerti situasi dan kondisi adat yang ada di sana, sehingga suku ini masih menjadi suku yang "terabaikan." 3

Ada banyak nilai-nilai positif dari budaya dan adat suku Komering yang merupakan etika, norma dan kearifan lokal yang sangat baik dan mulia yang didalamnya ada kejujuran, ketulusan dan kesetiaan akan janji yang dibuat, kesetiakawanan; tentu saja untuk memahami sampai kedalamnya kita sebagai orang luar dari suku ini harus masuk dalam kehidupan suku, (harus makan sepinggan, minum secangkir, mandi sesungai, nugal sehuma, njebak selubuk, sedendang-sepantun, duduk sepesta, segandengtangan waktu duka) ${ }^{4}$ dengan mereka barulah

\footnotetext{
${ }^{3}$ Kata "terabaikan" di sini menunujuk kepada belum terlayaninya suku ini oleh berita Injil, oleh karena berbagai macam hal atau kendala, sehingga suku ini belum menerima Kabar Baik, karena tidak adanya pekerja yang diutus atau menggarap ladang pelayanan di tengah-tengah suku ini.

${ }^{4}$ Untuk diterima menjadi bagian dari suku ini kita harus bisa makan bersama dalam piring yang sama, minum kopi dengan cangkir yang sama, bersama-sama mandi di sungai yang sama, menanam padi tebing bersama dalam satu ladang, menangkap ikan bersama dalam satu Lubuk/danau kecil di rawa-rawa, saling mengerti adat istiadat yang biasanya tertuang dalam syair dan pantun yang penuh kiasan-kiasan, ikut dalam
} 
kita akan mengerti akan hati suku ini yang sesungguhnya. Salah satu budaya atau adat yang ada di suku Komeringa adalah adat "Angkan-angkanan," yaitu saling mengikat perjanjian menjadi satu keluarga dengan cara mengangkat salah satu anak dari salah satu keluarga mereka menjadi anak dari keluarga yang lain. Dan melalui satu anak ini kedua keluarga dipersatukan menjadi satu keluarga atau saudara dengan ikatan atau janji yang abadi atau kekal, tak seorangpun bisa membatalkan ketetapan janji ini.

Penulis melihat suatu percik cahaya melalui Angkan-angkanan ini; bukankah mengangkat anak atau adobsi bagi suku ini merupakan hal yang sangat penting dan memiliki arti yang sangat khusus. Sehingga sebagai hamba lintas budaya kita bisa mengkorelasikan tentang bagaimana secara iman kita di adobsi menjadi anak-anak di dalam Tuhan yang juga menjadi janji kekal dalam kehidupan manusia lama ke dalam kehidupan baru masuk dalam keluarga Allah. Penulis berharap melalui paparan Adat Angkan-angkanan ini kita diperkaya memahami suku Komering dan dengan hikmat dari Tuhan kita bisa masuk ke dalam kehidupan dan budaya suku ini.

\section{Latar Belakang Angkan-angkanan}

Istilah angkan-angkanan dalam bahasa Komering berasal dari kata 'angkat' yaitu mengangkat orang lain atau membuat orang lain menjadi saudara atau bagian dari keluarga umumnya menjadi anak, yang sebelumnya tidak ada hubungan tali persaudaraan atau keluarga. Sedangkan akhiran 'an' mengandung arti 'saling' saling mengakui atau bersepakat antara kedua belah pihak secara sungguh-sungguh.

Sampai saat ini di dalam budaya suku Komering yang terus berkembang mengikuti zaman dan pengaruh kemajuan informasi melalui media dan perjumpaan dengan budaya luar seperti datangnya perantau dan transmigran dari Jawa dan Bali, adat Angkan-angkanan masih tetap ada dan dilestarikan sebab sudah menjadi bagian dari kehidupan suku Komering. Secara umum angkan-angkanan terjadi atau dilaksanakan karena adanya peristiwa atau hal-hal yang melatarbelangkangi; yaitu tiga hal yang melatarbelakangi tradisi atau adat "angkan=angkanan."

\section{Penyelesaian Konflik}

Seperti yang sudah penulis uraikan dalam pendahuluan, bahwa karakter atau sifat suku Komering yang cenderung temperamental; mudah tersinggung, mudah marah yang acap kali hal-hal yang sepele seperti perbedaaan pendapat, iri hati sering karena bersenggolan waktu menari (joget) di waktu ada pesta bisa menimbulkan pertikaian, perselisihan dan permusuhan diantara anggota masyarakat suku Komering itu sendiri atupun dengan suku-suku lain. Dalam setiap persoalan dalam budaya-budaya suku termasuk suku Komering pasti ada jalan keluar untuk menyelesaikan persoalan yang ada sehingga persoalan-persoalan itu tidak mengganggu dan menjadi konflik berkepanjangan di dalam kehidupan dan keharmonisan suku itu sendiri.

Dalam budaya suku Komering ada sebuah tradisi yang dipakai untuk menyelesaikan persoalan yang terjadi; semisal ada seseorang yang bersalah kepada orang lain maka harus

perayaan atau pesta yang ada dan saling membantu bila ada yang kedukaan. Artinya hidup sama luar dalam seperti mereka adanya. 
segera diselesaikan sebab kalau tidak, akan menjadi dendam sampai 'tujuh turunan'5. Orang yang bersalah harus segera menebus kesalahannya dan dalam budaya adat suku Komering desebut "Nyalah Sifat". Dalam pelaksanaannya nyalah sifat ini biasanya diadakan "sedekah"6 sebagai bagian dari upacara penebusan kesalahan yang selanjutnya dilanjutkan dengan "angkan-angkanan", jadi nyalah sifat tidak bisa dipisahkan dengan tradisi angkanangkanan. Sudah menjadi tradisi masyarakat suku Komering bila terjadi konflik atau permasalahan harus didamaikan dengan upacara "nyalah sifat" yang kemudian dilanjudkan dengan "angkan-angkanan". Maksud dari angkan-angkanan adalah sebagai pertanda bahwa persoalan di antara mereka (kedua belah pihak) sudah selesai, dan sebagai bukti dari perdamaian itu ialah mereka saling mengangkat atau mengakui sebagai keluarga.

Sekitar tahun 70-an keluarga penulis seorang ibu memiliki dua orang anak laki dan perempuan yang masih remaja, ibu ini berobat ke mantri kesehatan orang Komering bernama Bapak Habibur (kami biasa menyebut Pak Bibur) dan karena satu dan lain hal (sekarang kita sebut mal praktek) ibu tersebut meninggal dunia. Dan untuk menyelesaikan persoalan ini akhirnya pihak bapak mantri kesehatan Habibur menebus salah dengan membantu biaya pemakaman dan segala keperluan upacara dan penghiburan sebagai : "nyalah sifat" dan juga mengadakan angkan-angkanan: anak laki-laki dari ibu ini namanya "ANTO" diangkat menjadi anak dari keluarga Habibur dengan hak yang sama dengan anak-anak beliau, juga jaminan untuk pendidikan bagi Anto disediakan. Namun setelah Anto menginjak pemuda dia pulang ke Jawa sampai sekarang dikarenakan akhirnya Ayahnya juga meninggal dunia karena usia tua.

Sehubungan dengan pelaksanaan "angkan-angkanan," yang disebabkan karena terjadinya konflik atau perselisihan, apabila seseorang kedapatan melakukan suatu kesalahan terhadap orang lain, misalnya mencemarkan nama baik seseorang, mencuri, melukai, mencelakai atau merugikan orang lain baik sengaja ataupun tidak sengaja, maka orang itu harus mendapatkan hukuman setara denga apa yang diperbuat. Bahkan jika membuat orang lain meninggal maka hukumnya adalah "nyawa ganti nyawa," yang artinya bila ada seseorang mencelakai atau membunuh maka pihak keluarga akan berusaha juga membunuh orang tersebut; namun demikian secara adat ada cara lain yang bisa dipakai untuk menyelesaikan konflik ini tanpa adanya kekerasan atau pembunuhan.

Dalam menyelesaiakan masalah dalam adat 'nyawa ganti nyawa' dapat diselesaikan secara kekeluargaan, sesuai dengan adat istiadat yang berlaku di dalam masyarakat suku Komering. Pihak yang bersalah harus mengadakan "nyalah sifat" kepada pihak yang dirugikan sebagai tanda atau bukti permohonan maaf atau sebagai penebus kesalahan, baik kesalahan yang disengaja atau kesalahan yang tidak disengaja. Dalam pelaksanaanya pihak yang bersalah harus membawa seperangkat persyaratan yang sudah ditentukan di dalam adat suku Komering.

\footnotetext{
${ }^{5}$ Maksud dari dendam tujuh turunan adalah bahwa suku Komering bisa memiliki konflik dan mendendam, dan dendam itu diwariskan sampai ke anak cucu; jadi tidak mengherankan bila tiba-tiba ada seseorang yang tidak tahu sebabnya tiba-tiba dianiaya, ditusuk dengan badik sampai meninggal; kemungkinan besar keluarga atau orang tua bahkan kakek, kakek buyutnya ada dendam yang tak terselesaikan.

${ }^{6}$ Dalam adat Komering kata "sedekah" berarti pesta atau acara makan bersama dengan berbagai makanan yang harus disediakan; seperti nasi putih dengan lauk pauk, ikan dan lalapan, Gulai Ayam, Pindang Ikan, Sambal Nanas atau Tempoyak (sambal durian); kedua belah pihak keluarga saling berhadapan melingkar duduk di lantai (rumah panggung) dan mengundang tua-tua adat dan makan bersama sebagai bagian dari acara nyalah sifat atau menebus kesalahan. Biasanya juga ada barang-barang yang harus dibawa sesuai dengan persyaratan yang ditentukan oleh pihak yang dirugikan atau benar.
} 
Apabila seseorang melakukan nyalah sifat, ada beberapa hal yang harus diperhatikan, diantaranya adalah: Pihak yang bersalah memilih seorang utusan untuk datang kepada pihak yang dirugikan. Seorang utusan dipilih berdasarkan rapat keluarga, dan yang berhak untuk dipilih adalah orang yang dituakan atau dianggap mampu; apabila diantara keluarga tidak ada yang bisa menjadi utusan maka atas persetujuan bersama bisa menentukan dan meminta pertolongan kepada pihak lain. Seorang utusan datang kepada pihak yang dirugikan didampingi oleh dua orang atau lebih dari pihak yang bersangkutan sebagaimana tradisi dalam melaksanakan nyalah sifat.

Seorang utusan dan pendamping berpakaian formal seperti dalam mengikuti acar-acara adat suku setempat, yaitu memakai kopiah dan memakai kain (sarung) yang dililitkan di pinggang. Selain menyiapkan sarana sedekah" bagi penyalah sifat biasanya membawa syarat dalam adat yaitu: beras, ketan hitam, kelapa, ayam betina dan uang sebesar tiga ringgit (tujuh ribu lima ratus Rupiah). Makna yang terkandung di dalamnya ialah: beras adalah bahan pokok untuk nasi dan ini menjadi kebutuhan hidup semua orang; ketan hitam sebagai lambang kenikmatan/kesempurnaan hidup, karena biasanya dibuat kue yang nikmat sebagai pelengkap pesta; kelapa adalah buah yang banyak kegunaanya, air kelapa bisa menawarkan racun, dagingnya bisa untuk bumbu memasak, untuk minyak goreng, namun untuk mengambilnya perlu memanjat dan perlu mengupas dua kali sehingga perlu perjuangan, dan orang hidup harus berusaha untuk mendapatkan hasil; ayam betina dagingnya untuk gulai yang nikmat dibanding daging yang lain, ayam betina memiliki sifat mengalah tidak suka bertarung, ini sesuai dengan tujuan nyakah sifatkenikmatan hidup bersama yaitu untuk berdamai dan menghasilkan kenikmatan hidup bersama; sedangkan uang adalah alat pembayaran yang syah, sebagai lambang kesanggupan untuk membayar atau menebus kesalahan yang telah diperbuat, dan mengganti kerugian yang diperbuat bagi yang dirugikan.

Setelah kedua belah pihak saling memaafkan dengan kesungguhan hati yang tulus, selanjutnya mereka akan mengikat tali persaudaraan dengan mengadakan upacara "angkanangkanan", yang bermakna diantara mereka saling mengakui sebagai keluarga sendiri; ini diadakan dalam acara adat sehingga diketahui oleh masyarakat sebagai semacam pemberitahuan atau pengumuman bahwa diantara mereka sudah tidak ada permusuhan lagi, dan perjanjian angkan-angkanan ini kekal hukumnya sampai keanak cucu.

\section{Sebagai Balas Budi}

Kebiasaan untuk membalas budi baik seseorang menjadi bagian dari kehidupan suku Komering; balas budi atau membalas kebaikan atau pertolongan orang lain dengan kebaikan juga. Sudah menjadi kebiasaan bagi masyarakat suku Komering apa bila ada orang yang memilikisikap atau tingkah laku dan perbuatan baik, akan dibalas dengan kebaikan juga. Bagi orang Komering kebaikan yang diterima dianggap sebagai hutang yang harus dibayar; oleh kareena itu setiap orang Komering yang mendapat kebaikan dari siapa saja, dan hal ituu memberi kesan tersendir memberi kesan tersendiri baginya, maka orang yang menerima kebaikan itu akan berusaha untuk membalasnya.

Membalas kebaikan yang dimaksud disini bukan dengan harta benda, melainkan dengan mengangkat mereka menjadi saudara atau keluarga. Bagi masyarakat suku Komering, budaya "Angkan-angkanan," dilakukan bukan berdasarkan besar kecilnya perbuatan atau kebaikan yang dilakukan, melainkan kesan yang terkandung di balik perbuatan baik tersebut. 
Kesan tersebut akan membuat mereka memiliki hubungan yang baik satu sama lain. Supaya hubungan tersebut tetap berlanjut dan tidak putus, maka diikat atau diteguhkan dalam acara adat "angkan-angkanan."

Nama dan Wajah yang mirip

Menurut adat suku Komering, apabila seseorang memiliki kemiripan wajah dan nama yang sama dengan dirinya atau salah satu keluarganya, baik yang masih hidup atau yang sudah meninggal dunia, mereka dapat mengangkan. Menurut kepercayaan suku ini kemiripan nama dan wajah itu terjadi karena adanya ikatan roh; atas dasar inilah mereka ingin menyatukan orang tersebut dengan keluarga mereka.

Apabila sebut saja si A bertemu dengan seseorang sebut saja si B yang memiliki nama atau wajah yang mirip dengan dirinya atau salah satu keluarganya, maka si A ini akan menanyakan keberadaan si B dan kemudian menyampaiakan kepada keluarga perihal terebut. Dan setelah disampaikan kepada keluarga dan mereka merasa terharu mendengar hal itu, maka akan diputuskan agar ada yang mewakili keluarga untuk datang ke rumah orang tersebut (si A); biasanya yang menjadi utusan adalah salah satu keluarga yang dituakan atau orang lain yang sudah dipercaya.

Maksud kedatanganya untuk menyampaikan maksud keluarga besar bahwa salah satu anggota keluarga tersebut ada yang mempunyai nama yang sama atau memiliki kemiripan wajah dengan salah satu keluarganya. Biasanya "angkan-angkanan" karena kesamaan nama atau kemiripan wajah dilakukan selain dianggap sanak (saudara) juga karena orang tersebut memiliki nama yang sama atau wajah yang mirip dengan salah satu keluarga yang telah meninggal atau merantau (pergi jauh).

Dikatakan oleh suku ini, bila kita bertemu dengan orang yang memiliki nama yang sama atau wajahnya mirip maka kesan yang timbul adalah perasaan terharu. Timbulnya perasaaan terharu tersebut karena di dalam hati kita ada kontak batin yang menunjukkan bahwa kita memiliki hubungan batin dengan orang tersebut. Ada dua jenis saudara kembar di9 dunia ini, saudara kembar yangsekandung dan saudara kembar yang tidak sekandung. Saudara kembar yang tidak sekandung dapat ditemukan pada diri seseorang yang memiliki kesamaan nama, kemiripan wajah dan kemiripan sikap, tingkah laku yang lain; oleh karena itulah mereka dapat saling mengangkan. Mengenai upacaranya tergantung pada kesepakatan bersama. Bisa salah satu yang mengadakan atau bisa juga kedua-duanya yang menyelenggarakan acara angkan-angfkanan; namun biasanya dalam hal ini dilakukan oleh pihak yang memiliki inisiatif untuk mengangkan. Tujuan dalam angkan-angkanan di sini adalah untuk mengembalikan terpisahnya tali silaturahmi atau persaudaraan dalam keluarga mereka.

\section{Mengikat Hubungan Baik}

Hal lain yang bisa dijadikan alasan untuk 'mengangkan' seseorang adalah karena hubungan baik yang terjalin, ini sering terkadi biasanya karena pertemanan sejak kecil atau persahabatan di tanah rantau yang baik sehingga mereka menjadi sahabat setia dalam suka dan duka, atau setidaknya menjadi sahabat baik. Karena persahabatan ini biasanya mereka biasa 
untuk berkunjung ke rumah sahabatnya, kadang makan minum dan bermalam atau tinggal beberapa hari bila ada acara, misalnya "sedekahan" atau sedang menugal (menanam padi tebing) ikut membantu keluarga sahabatnya; bagi keluarga itu ia sudah menjadi bagian keluarga atau dianggap anak dari keluarga sahabatnya itu.

Seumpama antara kedua sahabat ini berjauhan tempat tinggalnya, maka bila salah satu dari mereka berkunjung ke rumah sahabatnya atau berada di daerah sahabatnya; maka sahabatnya dan seluruh keluarganya akan memberi perlindungan dan menjamin keamanan bila ada di daerah itu, dari orang jahat, anak-anak nakal, dan lain sebagainya.

Penulis sendiri memiliki sahabat baik di tengah suku ini, namanya "Sahrowi," menjadi teman karena sama-sama duduk di bangku pendidikan dari SD sampai SMP, sedangkan saat masuk Sekolah Guru sahabat saya tidak lolos seleksi dan meneruskan ke SMA, dan kami berpisah dalam studi; namun pertemanan tetap terjalin. Dan sampai sekarang bila penulis berada di Komering, penulis akan berusaha berkunjung ke kekeluarga Sahrowi. Walaupun belum sampai diangkat menjadi keluarga dalam adat "angkan-angkanan," karena persahabatan waktu itu terjalin dalam usia anak-anak menuju remaja, tetapi alasan seperti di atas bisa menjadi alasan untuk mengangkat sahabat ini ke dalam adat "angkan-angkanan."

\section{Dalam Pernikahan}

Dalam pernikahan sebenarnya juga merupakan bagian dari "angkan-angkanan" karena menyatukan kedua belah pihak keluarga menjadi kluarga baru, terutama anak-anak (mempelai berdua) menjadi bagian dari keluarga dari kedua belah pihak. Kata anak menantu hanya istilah dalam pengertian umum, namun sesungguhnya diangkat menjadi anaknya sendiri dan sebaliknya sang anak menantu menjadikan mertua adalah orang tuanya sendiri; juga anggota keluarga yang lain seperti kakak, adik, kakek, nenek, bibi dan paman; juga kerabat yang lain menjadi keluarga sendiri.

Oleh karena itu dalam adat pernikahan tidak lagi diadakan acara adat "angkanangkanan;" karena sudah begitu jelas bahwa pernikahan secara filosofi adalah mengangkat dan menyatukan keluarga yang berbeda (dua belah pihak) menjadi satu keluarga besar.

\section{Pelaksanaan Angkan-angkanan}

Dalam melaksanakan "angkan-angkanan," ada hal-hal yang sudah diketahui bersama di dalam masyarakat suku Komering; yaitu ketentuan yang tidak tertulis tentang siapa sesungguhnya yang bisa diangkan (diangkat) menjadi keluarga, juga bentuk upacara itu sendiri, atau dengan kata lain bagaimana upacara angkan-angkanan itu dilangsungkan.

Siapa yang di-Angkan atau Mengangkan?

Mengenai siapa yang mengangkan dan siapa yang di angkan, dalam masyarakat suku Komering tidak ada pengecualian, semua orang dalam suku Komering dapat melakukan adat angkan-angkanan ini. Jaadi mengangkan dan diangkan dapat dilakukan oleh siapa saja; 
dengan kata lain tidak dibatasi status sosial seseorang. Pelaksanaan dalam "angkanangkanan" apabila karena suatu peristiwa misalnya kecelakaan; maka yang mengangkan adalah pihak yang menabrak atau merugikan, bila terjadi perkelahian maka yang mengangkan adalah orang yang melakukan kesalahan. Namun bila terjadi karena perbuatan baik atau hubungan baik maka yang mampu yang mengangkan; bila angkan-angkanan itu terjadi antara orang tua dan seorang anak, maka orang tua yang mengangkan.

Budaya angkan-angkanan tidak melihat atau membedakan ras suku dan golongan dan agama. Menurut adat suku Komering siapapun dapat diangkan dan mengangkan; angkanangkanan tidak hanya dilakukan antara suku Komering saja, tetapi bisa dengan suku di luar suku Komering. Jadi budaya atau adat angkan-angkanan ini memiliki arti bahwa: Masyarakat Suku Komering terbuka, dapat bersahabat dan menerima orang lain.

\section{Upacara Angkan-angkanan}

Upacara angkan-angkanan dilaksanakan setelah dilakukan musyawarah oleh kedua belah pihak melalui utusan-utusan atau wakil keluarga. Selanjudnya kedua belah pihak menentukan waktu pelaksanaan angkan-angkanan, kapan waktu pelaksanaan dan tempat diadakan upacara adat angkan-angkanan itu. Upacar angkan-angkanan bisa dilaksanakan secara khusus atau bisa juga diikutsertakan dengan upacara yang lain, seperti pernikahan atau khitanan. Upacaara bisa dilakukan oleh salah satu atau kedua belah pihak, tergantung dari hasil kesepakatan dalam musyawarah yang telah dibuat bersama. Sedangkan yang berhubungan dengan biaya untuk "sedekah" atau persedekahanh" atau persedekahan biasa biasanya ditangnya ditanggung oleh pihak yang mengadakan upacara "anngkan-angkanan" tersebut.

Di dalam upacara angkan-angkanan ini akan dihadiri oleh kepala adat atau Pemangku Adat atau sesepuh desa setempat, dan mengundang masyarakat sekitar untuk menyaksiakan bahwa keluarga tersebut telah melaksanakan upacara "angkan-angkanan". Dalam kesempatan upacara tertsebut salah satu keluarga menceritakan maksud dan tujuan serta latar belakang sehingga diadakan Upacara angkan-angkanan atau latar belakang mengangkan saat itu; memperkenalkan nama yang akan diangkan, asal dan hal-hal lain, kemudian akan dijelaskan status dalam keluarga pengangkan, sebagai anak, keluarga atau orang tua. Dalam upacara ini keluarga kedua belah pihak ditempatkan di depan para uandangan sedekah yang lain agar dapat dilihat oleh semua hadirin.

Setelah maksud dan tujuan angkan-angkanan disampaikan, maka diteruskan dengan acara persedekahan atau makan bersama. Persedekahan biasanya diadalkan dengan hidangan istimewa atau pesta; sesuai dengan kemampuan keluarga bisa memotong ayam, kambing, yang mampu akan memotong sapi atau kerbau.

\section{Hak dan Kewajiban}

Dalam adat budaya "angkan-angkanan" suku Komering tidak ada peraturan secara tertulis atau dibakukan hak dan kewajiban antara pengangkan dan yang diangkan; namun secara norma atau etika tradisi adat secara otomatis antara kedua belah ada dan harus melaksanakan hak dan kewajiban sebagai angota keluarga, atau sebagai anak atau sebagai 
orang tua; jadi keduanya sudah saling mengerti dan menyadari akan tugas, hak dan kewajibannya.

\section{Hak Keluarga Angkat}

Sebagai anak misalkan seseorang diangkan sebagai anak, ia berhak mendapatkan perhatian dari orang tuanya atau keluarga barunya. Wujud perhatian dari keluarga dan orang tua ini tidak hanya dalam wujud materi, namun juga berhak mendapatkan perhatian dan kasih sayang dari keluarga atau orang tua angkatnya. Sebagai saudara, ia juga berhak untuk mendapatkan perhatian dan dipedulikan seperti layaknya saudara kandung.

Mengenai harta warisan dari orang tua angkat, hal itu dipandang sebagai pemberian dan bukan seseuatu yang harus dituntut oleh anak angkat dari orang tua angkatnya. seorang anak angkat diberi atau tidak diberi warisan itu sepenuhnya tergantung dari orang tua angkatnya; karena warisan ini bentuknya adalah pemberian, jadi menurut kerelaan orang tua angkatnya; dan dalam budaya angkan-angkanan tidak ada perjanjian atau hukum adat yang mengharuskan memberikan warisan.

\section{Kewajiban Keluarga Angkat}

Dalam angkan-angkanan ini yang diatur adalah struktur dalam keluarga angkat. Apabila terjadi angkan-angkanan antara orang tua dan anak muda, maka kedudukan dalam keluarga adalah sebagai orang tua dan anak; apabila yang angkan-angkanan memiliki umur sebaya, maka kedudukan mereka adalah sebagai kakak adik.

Kewajiban orang tua setelah mengangkat anak, anak yang menjadi tanggung jawabnya sebagaimana layaknya orang tua memperhatikan dan memelihara anaknya; sedang anak harus menghormati orang tua angkan sebagaimana orang tuanya sendiri. Anak angkan berhak mendapat hak waris dari orang tua angkan, tetapi itu tergantung dari orang tua angkannya. Anak angkan memiliki hak waris $100 \%$ dari orang tua angkan apabila ia diangkan sebagai anak tunggal. Apa bila "angkan-angkanan" ini sebagai saudara, maka wajib menjalin tali silaturahmi, salaing memperhatikan dan membantu.

\section{Sistem Kekerabatan Sebagai Pintu Masuk}

Sudah diketahui bersama bahwa suku Komering memiliki sifat atau karakter yang keras dan emosional, sehingga sangat sensitif terhadap orang yang belum dikenal atau kepada pendatang baru; sehingga sebagai "hamba lintas budaya" harus mengetahui dari mana harus masuk ke dalam kehidupan suku Komering, salah satunya dengan cara angkan-angkanan ini.

Suku Komering sangat kuat dalam hal kekerabatan mereka; sistem kekerabatan itu tersusun rapi dan setiap orang suku Komering adalah bagian dari kekerabatan keluarga atau marganya, dengan demikian setiap orang memiliki tanggungjawab untuk menjaga dan melindungi kerabat dalam lingkar keluarga atau marga.

Sebagai bukti begitu kuatnya kekerabatan suku Komering tidak hanya terlihat dalam hal-hal kebaikan dan kebersamaan saling menolong, tetapi juga sampai kepada hal-hal yang negatif. Orang Komering rela membela dan melukai bahkan mencelakakan orang lain demi 
membela kerabatnya. Dampak negatif dari kekuatan marga dalam suku Komering ini adalah "emosi masal," yang artinya bila satu kerabat emosi maka yang lain juga akan emosi, sehingga bisa menimbulkan permusuhan yang lebih besar, itulah kebersamaan dalam kekerabatan suku Komering seperti semboyan mereka "Sebimbing Sekundang.",

Mengapa perihal ini bisa menjadi peluang bagi hamba lintas budaya? Meskipun orang Komering sangat keras namun akan sangt menjaga dan melindungi siapa saja yng ada di dalam sistem kekerabatan mereka, baik orang yang lahir sebagai suku komering dalam kerabat mereka atau orang luar yang telah diakui mejadi bagian keluarga atu marga mereka melalui adat angkan-angkanan. Jadi kalau hamba lintas budaya bisa menjadi bagian dari sistem kekerabatan mereka, maka hamba lintas budaya ini akan memiliki akses yang sangat luas dalam kehidupan bersama mereka. Apalagi bila hamba lintas budaya ini bisa diangkan sebagai anak atau saudara oleh orang kuat atau berpengaruh di dalam suku ini seperti Ketua Adat, Pesirah, Tumengung atau orang yang dituakan di dalam suku tersebut, maka kesempatan hamba lintas budaya ini akan terbuka lebar dalam hal penerimaan sebagai bagian dari suku Komering ini.

\section{Analogi Angkan-angkanan}

Setelah kita melihat latar belakang angkan-angkanan dan maknanya bagi kehidupan "manusia Komering," sesungguhnya mengandung pengerian dan kebenaran Alkitabiah yang bisa kita gunakan untuk mengajar mereka mengerti tentang kebenaran dalam Injil, seperti:

\section{Menurut rupa wajah yang sama}

Seperti telah diuraikan angkan-angkanan di budaya suku Komering bisa terjadi karena alasan kesamaan rupa/wajah. Sesungguhnya kita bisa mengajar kepada Suku ini bahwa manusia tidak hanya memiliki kemiripan atau hubungan antara manusia dengan manusia, namun lebih dari pada itu, manusia diciptakan serupa dan segambar dengan Allah, karna perseteruan antara manusia dengan Allah telah diperdamaikan. Melalui ini kita bisa menceritakan kebenaran firman Tuhan dari Penciptaan, Kejatuhan Manusia dan solusi Jalan Keselamatan yang ditawarkan Allah kepada umat manusia.

\section{Menjadi satu keluarga}

"Nyalah sifat," adalah alat stabilitas sosial di dalam kehidupan kasyarakat suku Komering; penebusan salah ini dilakukan untuik menyelesaikan permusuhan di antara anggota masyarakat suku Komering, sehingg di antara ke dua belah pihak antara yang benar dan salah/yng dirugikan dan yangmerugikan akhirnya berdamai dan malah menjadi satu keuarga. Ide ini sangat menolong kita dalam menjelaskan bagaimana kita umat manusia bisa menjadi Keluarga Allah karena telah "diperdamaikan." Setelah berdamai, kedua belah pihak

${ }^{7}$ Arti dari semboyan Sebimbing Sekundang adalah: Berjalan seiring saling bantu-membantu dalam melaksanakan suatu pekerjaan untuk mencapai suatu keberhasilan bersama yang menunjukkan kuatnya dan harumnya nama marga dalam kekerabatan mereka. 
yang dahulunya adalah musuh atau bermusuhan sekarang saling memaafkan dan mengampuni, bahkan menjadi keluarga dengan ikatan tali kasih yang sangat kuat.

Bukankah ide ini adalah suatu kebenaran yang Alkitabiah? sehingga hamba lintas budaya bisa memakai pengertian suku yang telah mereka miliki dan pahami, menjadi jembatan dan pintu masuk yang sangat relevan dan efektif.

\section{Kesimpulan}

Walaupun dalam data statistik Jaringan Riset Nasional 2010 menjelaskan bahwa masih di bawah 100 jumlah orang percaya dari total populasi 450.000 jiwa di dalam Suku ini, namun sesungguhnya kita bisa melihat peluang-peluang dan akses masuk yang sungguh terbuka melalui adat upacara angkan-angkanan ini; sehingga setiap hamba lintas budaya yang terbeban melayani di wilayah suku Komering yang sudah menjadi kabar burung bahwa suku ini keras, susah untuk dilayani dan menerima Injil tidak menjadi kecut dan ciut nyali, justru semakin belajar untuk menemukan cara-cara pendekatan yang efektif.

Kunci utama hamba lintas budaya di dalam suku ini adalah bagaimana sebagai orang baru atau orang yang datang dari luar suku Komering bisa menjadi bagian dalam kehidupan mereka; dengan kata lain hamba lintas budaya harus menjadi "orang Komering," bertutur kata, bertingkah laku dan menjunjung adat istiadat suku Komering. Karena kalau tidak ada penerimaan dari Masyarakat suku Komering ini sangat tidak mungkin hamba lintas budaya bisa menyampaikan kabar baik.

Saya senang menyadur kata-kata rasul Paulus:

Demikianlah bagi orang Yahudi aku menjadi seperti orang Yahudi, supaya aku memenangkan orang-orang Yahudi. Bagi orang-orang yang hidup di bawah hukum Taurat aku seperti orang yang hidup di bawah hukum Taurat, sekalipun aku sendiri tidak hidup di bawah hukum Taurat, supaya aku dapat memenangkan mereka yang hidup di bawah hukum Taurat. Bagi orang-orang yang tidak hidup di bawah hukum Taurat aku menjadi seperti orang yang tidak hidup di bawah hukum Taurat, sekalipun aku tidak hidup di luar hukum Allah, karena aku hidup di bawah hukum Kristus, supaya aku dapat memenangkan mereka yang tidak hidup di bawah hukum Taurat. Bagi orang-orang yang lemah aku menjadi seperti orang yang lemah, supaya aku dapat menyelamatkan mereka yang lemah. Bagi semua orang aku telah menjadi segalagalanya, supaya aku sedapat mungkin memenangkan memenangkan beberapa orang dari antara mereka. (1 Korintus 20-22)

Beberapa falsafah atau motto suku Komering yang bisa menjadi pesan moral dan etis di tengah suku ini: 


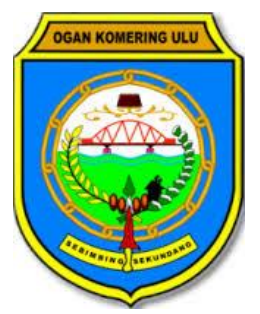

Motto Kabupaten Ogan Komering Ulu:

SEBIMBING SEKUNDANG artinya:Berjalan seiring saling bantu-membantu dalam melaksanakan suatu pekerjaan untuk mencapai suatu keberhasilan bersama yang menunjukkan kuatnya dan harumnya nama marga dalam kekerabatan mereka.

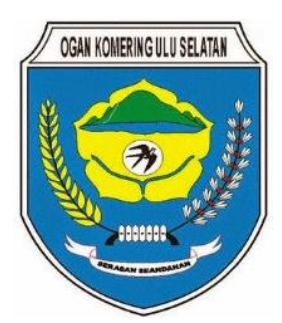

Motto Kabupaten Ogan Komering Ulu Selatan: SERASAN SEANDANAN artinya: Seiya Sekata Searah Setujuan; bermakna sepakat untuk mencapai tujuan yang akan dicapai dengan mengesampingkan kepentingan pribadi.

Motto Kabupaten Ogan Komering Ulu Timur: SEBIDUK SEHALUAN artinya Satu Perahu Satu Haluan mencerminkan bahwa masyarakat Ogan Komering Ulu Timur terletak pada suatu wadah kegiatan baik tani, dagang, pegawai dan lain sebagainya. Namun kegiatan tersebut tetap mempunyai tujuan yang sama yaitu membangun Kabupaten Ogan Komering Ulu Timur.

Motto Kabupaten Ogan Komering Ulu Ilir:

SEBENDE SEGUGUK artinya: bende artinya "gong" sedangkan seguguk adalah "1 kesatuan", arti dari seluruh lambang itu adalah kehidupan dengan semangat kesatuan dan persatuan untuk melanjutkan pembangunan, percapaian kemakmuran, kebahagian dan keadilan masyarakat. 


\section{DAFTAR PUSTAKA}

------. Alkitab. Jakarta; Lembaga Alkitab Indonesia, 2012

------. Kamus Besar Bahasa Indonesia. Jakarta; Balai Pustaka, 1990

-------. Indonesia Profil Suku-suku yang Terabaikan. Jakarta; Indonesia Pelangi NusantaraIPN, 2010

Sumber Media Internet

- media-okut.blogspot.com

- sumatera.infogue.com

- gambar-foto: campangtiga.blogspot.com

- gambar-foto: sosbud.kompasiana.com

- gambar-foto: media-okut.blogspot.com

- word-dialect.blogspot.com

- $\quad$ wikipedia

Sumber pribadi

Pengalaman hidup penulis yang lahir dan hidup di tengah-tengan suku Komering, BK O, Buay Madang, OKU Timur, Sumatera-Selatan. 